王娜

https://doi.org/10.15302/J-LAF-1-040021
美国景观设计师协会会员, SWA集团景观设计师

\section{城市滨水工业区的治理与重生: 美国休斯敦港景观规划设计 GOVERNANCE AND REBIRTH OF URBAN INDUSTRIAL WATERFRONT: LANDSCAPE PLANNING AND DESIGN FOR THE PORT OF HOUSTON, USA}

\section{1 背景介绍}

美国得克萨斯州休斯敦港航道集合了石油工业、交通运输和生态 资源等多重区位优势，长达 $84 \mathrm{~km}$ 。在过去的一个世纪里，休斯敦港一 直是得克萨斯州经济增长的主要动力。2018年数据显示, 休斯敦港为 整个州带来了 135 万个就业岗位和3 390亿美元的经济产值, 占全州GDP 的 $20.6 \%{ }^{[1]}$ 。然而, 在空间组织上, 休斯敦港与城市其他区域缺少互 动，市民与港口的联系也十分匮乏。与此同时，大型船舶的不断发展 增加了航道疏浚的需求，疏浚工程产生的泥沙堆积也不断侵占周边的 自然空间。港口所在的加尔维斯顿湾受海平面上升及港口工业发展的 长期影响，生态环境不断恶化，生物多样性严重减退。

为了应对港口面临的诸多挑战，休斯敦港务局（PHA）提出了 “2045年休斯敦港空间总体规划”（以下简称“2045规划”），同时 与美国陆军工程兵团 (USACE) 合作，保障港口航道及周边海域的 生态环境安全。本文所述项目以 2045 规划为契机，针对港口生态、文
摘要

随着大城市人口密度的提高, 城市工业区 不断寻求新的发展以实现工业景观从单一职能向 多功能系统的转变, 为城市提供更多的公共活动 空间。一个多世纪以来，休斯敦港工业区集合了 石油工业、交通运输和生态资源等多重区位优 势, 一直是当地经济增长的主体推动力; 然而, 港口工业发展及经济增长的背后却是与周边城市 界面的严重分隔。休斯敦港景观规划设计项目以 “2045年休斯敦港空间总体规划”为契机，面对 生态环境挑战、城市空间格局重新定位等问题, 通过景观规划设计手段从激活城市空间和修复生 态环境层面对港区进行治理, 期望打造经济一社 会 - 生态复合型滨水工业区。项目希望在保障休 斯敦港现有职能的同时，使之成为城市治理进程 中推动区域活力和增强生态㓞性的重要力量。

\section{关键词}

城市治理；滨水工业区；城市激活；城市空间； 生态修复；休斯敦港
WANG Na*

ASLA; Landscape Designer of SWA Group

*Corresponding Author

Address: 712 Main St 6th Floor. Houston Texas 77002 USA

\section{ABSTRACT}

With the increase of population in big cities, urban industrial districts are constantly seeking new development to realize the conversion from single-functional to multifunctional systems, to equip the city with diverse public spaces. The Port of Houston operates at the dynamic confluence of industry, transportation, and ecological systems, and has been a major driver of Houston's economic growth over the last century. However behind the prosperous economic growth, the port suffers from the isolation with the surrounding communities. Based on the " 2045 Port Houston Master Plan," the Landscape Planning and Design for the Port of Houston project focuses on urban space activation and ecological environment restoration through landscape planning and design methods, while facing the challenges of ecological environment, urban spatial pattern repositioning, and other urban issues. The project is expected to build an economically, socially, and ecologically healthy industrial waterfront zone. Port Houston, beyond its primary function as an economic driver, becomes a more visible and substantial force in urban governance of advancing the region's activation and resilience.

\section{KEYWORDS}

Urban Governance; Industrial Waterfront; Urban Vitalization: Urban Space; Ecological Restoration Port Houston 
用地分类分析图清晰地 反映出工业用地将居住 组团割裂开来, 滨水区 仅有零星的公共绿地空 间。项目设计场地的两 个区域如图所示。

Land use map showin industrial space splits the community space with little public green space along waterfron The site of this project consists of two areas, shown as Area 1 and Area 2.
化、社会等层面的问题, 以期通过景观设计的途径, 将港口打造成为 满足城市当代及未来需求的复合型滨水工业区。

\section{2 项目调研与问题发现}

本次设计的场地分为两个区域。区域一位于休斯敦港区起始段， 场地上有大量工业腾退遗留的废弃工厂, 港口游客中心和PHA总部大 楼也坐落在此, 航道周边紧邻多个大型居住区; 区域二位于海湾入海 口, 紧邻休斯敦港大型停靠码头, 是出人休斯敦港的门户水域, 分布 有多个由疏浚泥沙堆积的人工岛 (图1)

在设计之初, 项目团队与PHA进行了多次意见交流, 并从水路和
陆路进行了详尽的场地考察; 同时，通过座谈会向沿岸不同城市的管 理部门及市长了解了周边城市的环境、经济和文化发展情况。

\section{1 港口与城市割裂}

通过梳理休斯敦港产业发展脉络及收集公众参与反馈，设计团队 发现，港口与城市的紧密联系日渐消逝。历史上，休斯敦港口周围有 着丰富多样的生产、交易和休闲娱乐活动, 城市由港而生, 港口经济 支撑了城市的发展。而如今, 过于单一的第二产业职能限制了港口和 城市的良性互动, 在过去的几十年里, 休斯敦市向内陆不断扩展, 进 人了一个脱离港口的自增长过程 ${ }^{[2]}$; 出于安全考虑, 港口区与城市之 间建立起了长达数公里的铁网围栏，大部水域被隔离在城市生活区之

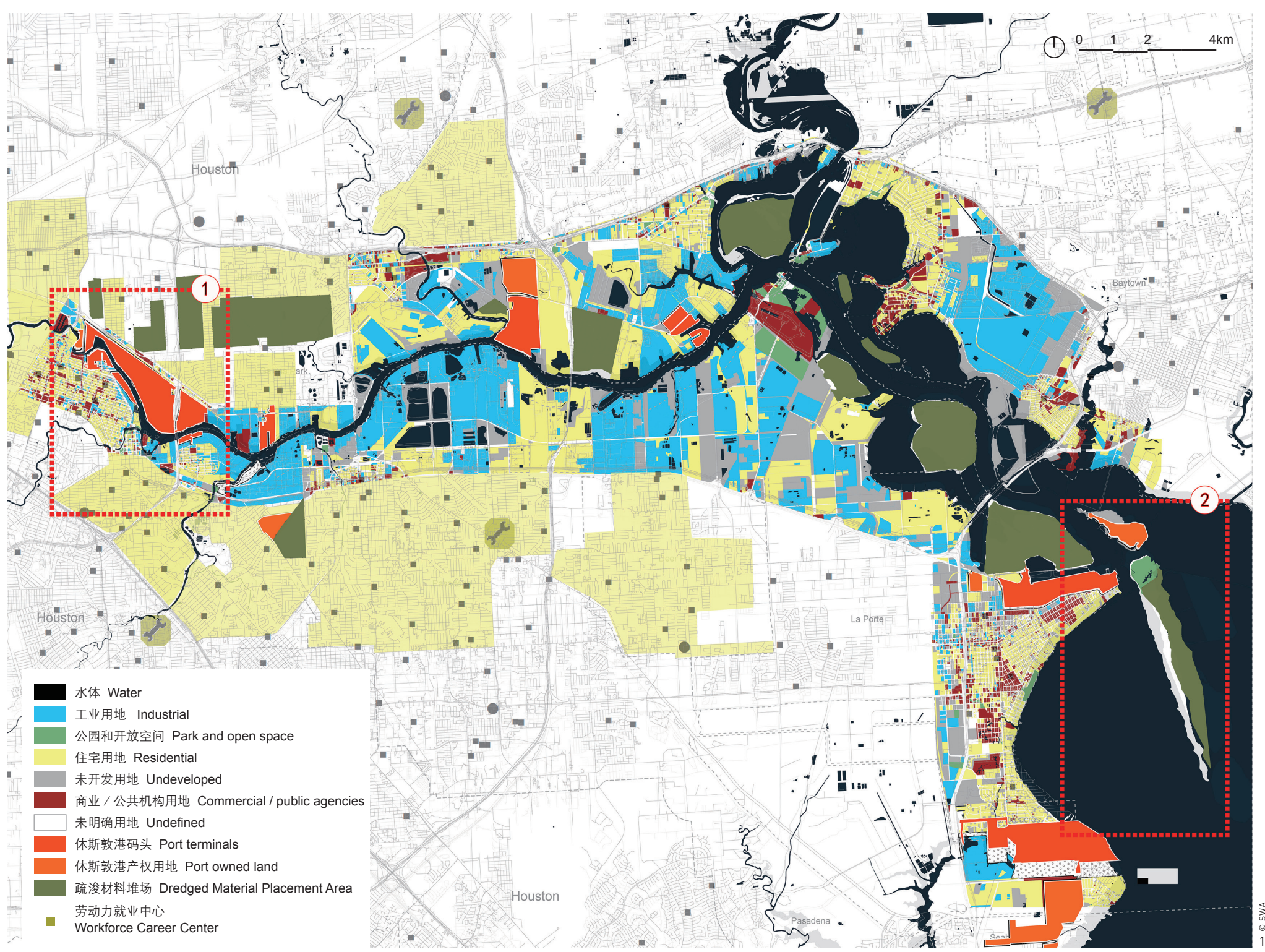


外，向公众开放的部分极为有限。因此，市民难以前往港口区进行休 闲娱乐活动，而港口也缺乏向城市展示其职能的窗口一一作为美国最 大的工业港口，休斯敦港几乎与这座城市完全脱离。

休斯敦是极个别没有分区规划的美国城市之一, 航道沿岸的 6 个建 造时间较早的居住区组团缺乏健全的配套基础设施规划，仅在近几年 建造了零星的社区公园。此外, 港口的地理位置强行将各个社区从空 间上割裂开来，使得原本就缺乏活力的社区更加孤立，交流互动仅局 限于各个社区内部。

与此同时, 休斯敦的未来城市定位和发展动力在很大程度上仍取 决于港口能否在制造业的基础上引入派生产业, 包括与港口相关的金 融业、旅游业、服务业等。

\section{2 工业港口侵占大量生态空间}

有别于大部分沿海港口，除线性水域以外，休斯敦港的产业范 围覆盖了整个海湾 $600 \mathrm{~km}^{2}$ 以上的水域, 包含海岸草原、河岸森林、湿 地、牡蚛礁、海草草甸 ${ }^{[3]}$ 等多种栖息地类型，为区域内大量植物、鱼类 及其他野生动物物种提供了赖以生存的空间。更为重要的是, 休斯敦 位于北美候鸟迁徙中央飞行路线沿线 ${ }^{[4]}$, 城市湿地及林地空间一直是候 鸟迁徙途中的驻足地。然而，港口的发展侵占了大量自然空间，在人 海口处不断建造的疏浚材料堆场 ${ }^{\circledR}$ 破坏了候鸟的栖息地。此外, 原油泄 漏造成的污染也使得海湾的水生生物多样性急剧下降 ${ }^{[5]}$ 。原有的海水养 殖和捕渔业不复存在, 原本景色宜人的动植物天堂被繁忙的机械操作 和轮船运输场景所取代。

\section{3 疏浚材料堆场空间闲置}

在实地踏勘中设计团队发现，两个区域场地上均分布着大量的疏 浚材料堆场（图2），但现有植被类型单一，多为野生植被。疏浚材料 处理一直是航道发展的热点话题, 休斯敦港数十公里航道需要持续的 疏浚工程来保持船只吃水深度要求, 其工程量之大、消耗人力物力之 多是美国其他空间紧凑排布的大型工业港口（如西雅图、纽约、洛杉矶 等) 都很少面临的挑战。休斯敦港口沿岸分布着 15 处疏浚材料堆场 ${ }^{[6]}$, 每 年航道疏浚作业的花费高达7 000万美元 ${ }^{[7]}$ 。由于现存的几处堆场已经达 到最大容量, 2045规划计划对其中几座现有堆场进行扩容并新建数座 疏浚材料堆场人工岛。 ${ }^{[8]}$ 大面积已经达到最大容量的闲置堆场空间如何 再生利用成为了未来皮待解决的课题。

\section{3 设计策略}

通过研究其他美国滨水工业区景观规划项目，包括底特律东滨河 区框架规划 ${ }^{[9]}$ 、纽约曼哈顿滨水区规划设计 ${ }^{[10]}$ 、波特兰滨水工业区改 造 ${ }^{[1]}$ 等, 总结出针对滨水工业区环境治理的基本准则：以生态修复为根 本，充分考虑滨水空间生态韧性对城市的反哺作用，从而提升空间活 力、丰富空间职能。

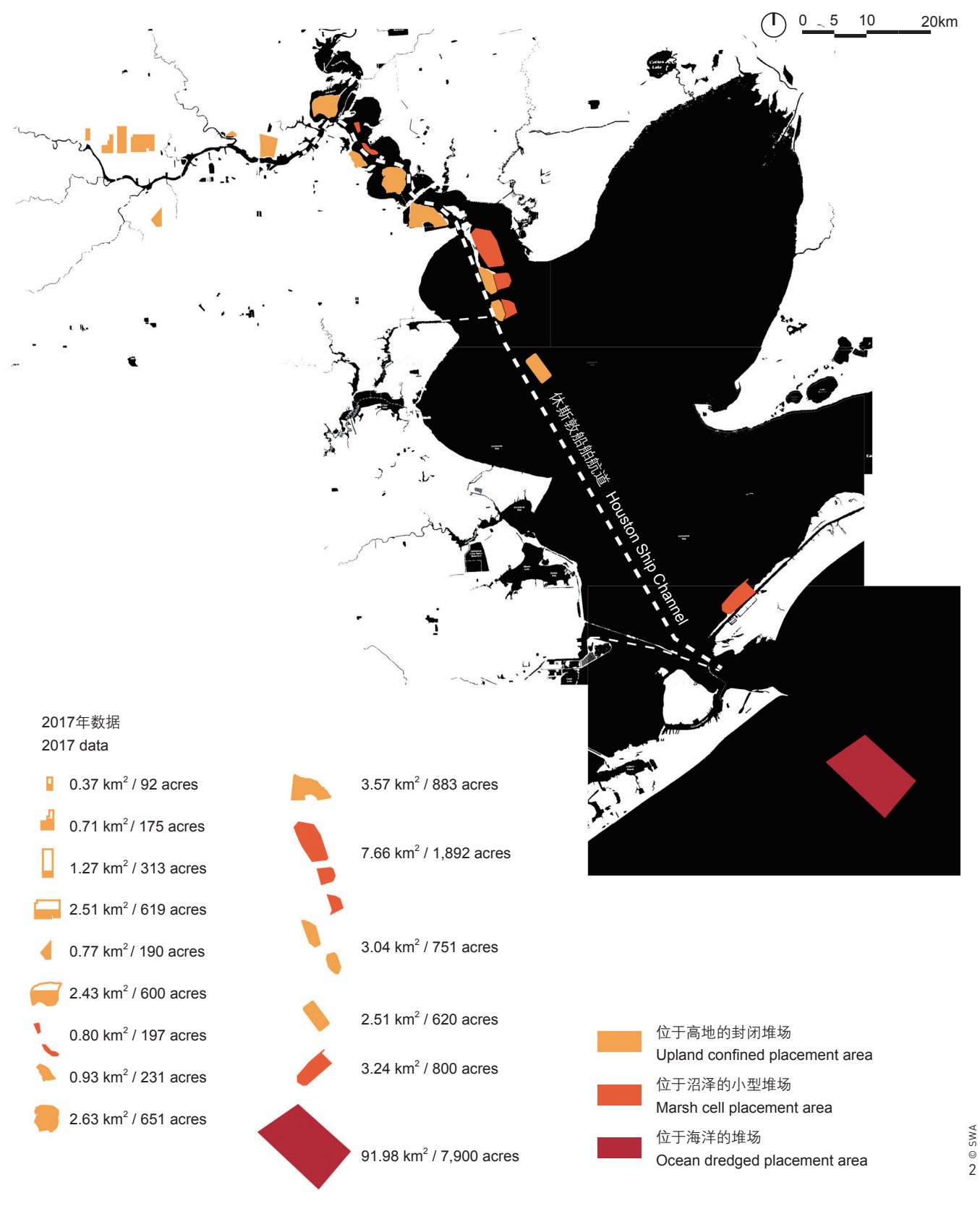

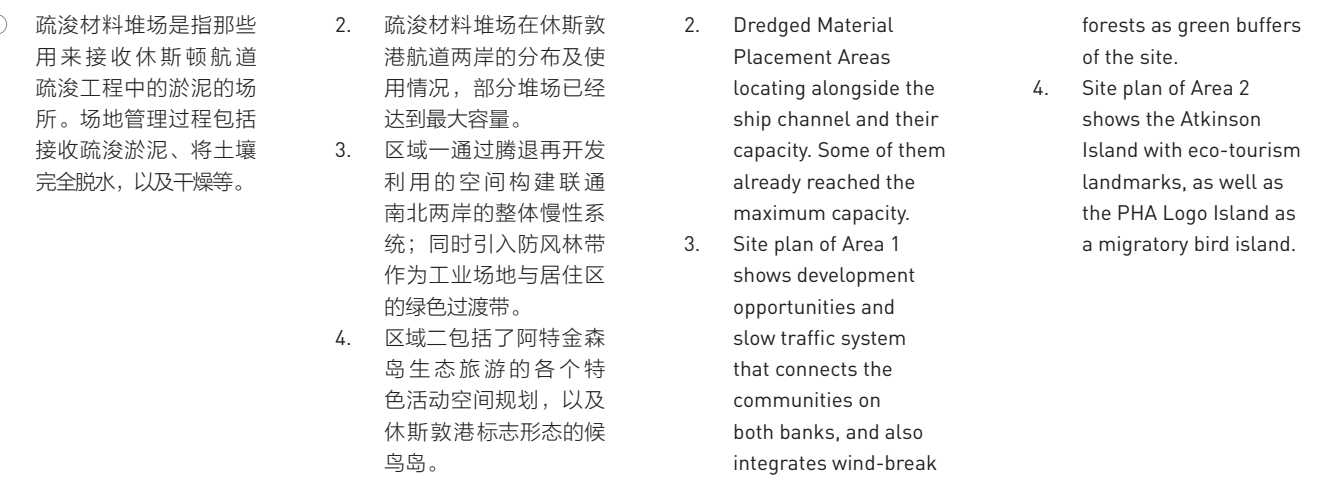



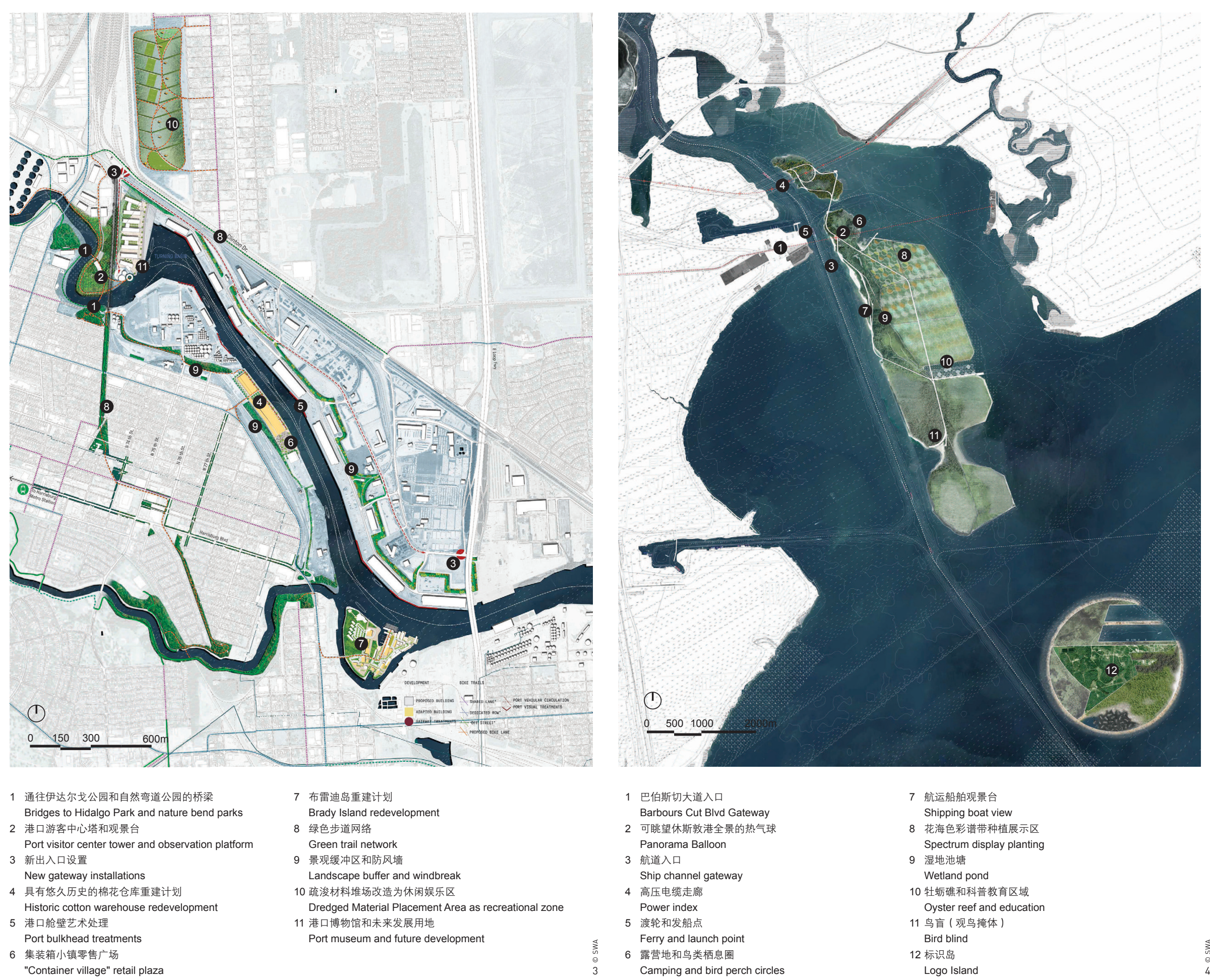

通过研究场地问题, 项目以城市激活与生态景观修复为首要设 计目标，制定了四大设计步骤：首先，要打破城市与港口空间上的隔 离, 让场地与城市实现动线联通; 其次, 实施环境空间治理, 恢复场 地的基本生态职能; 而后, 创造丰富多样的公共活动空间, 激活整个 片区、完善社会职能; 最终, 通过空间艺术提升途径, 促进场地与城 市的融合、丰富滨水工业区的文化职能。

\section{1 打破割裂：建立城市一港区慢行系统}

由于休斯敦未经过分区规划，城市交通网络中人行道极度缺乏、 行人交通事故死亡率一直居高不下。设计团队结合公众参与反馈中对 安全的户外步行、骑行运动线路的需求，打造了连接港区与城市社区 的慢行系统。设计结合正在规划建设的休斯敦城市绿色步道网络，开 辟骑行及步行专用道，在社区尺度建立完善、安全的慢行网络; 通过 
步道联通各个社区，并将人流引人场地，为市民提供社交及休慜机会 (图3,4)。

慢行系统建设最大的挑战是协调人流动线与港口工业交通流线。 设计团队与PHA通过多次讨论和现场踏勘, 在保证场地机动车交通环 线的基础上，减少部分机动车道、增加步行及骑行空间；同时整合港 口作业区空间, 仅在部分需安全保护的作业场区保留铁网围栏。设计 保留航道水系曾经的运输桥梁作为历史景观遗迹, 并建设平行跨河桥 梁、串联起周边社区公园，从而打破南北两岸社区一直以来的地理隔 离（图5)。

\section{2 空间治理: 修复场地生态环境}

设计团队通过疏浚材料堆场净化再利用、海岸线修复、候鸟鸟岛 重建等途径逐步恢复被工业开发侵占的自然生态系统, 并增强沿海工 业区的生态韧性。

作为正在运行的工业港口, 设计团队很难在场地中直接引人大面 积公共绿地, 水域空间也必须满足通航需求。场地上大量闲置的疏浚 材料堆场空地成为了可以利用的重点。多年来, PHA尝试用疏浚泥沙 在区域二的疏浚堆场上初步建造示范湿地 ${ }^{[12]}$ (图6), 计划在50年的周 期内 $^{[13]}$, 在达到堆场容量并完成疏浚材料沉淀和脱水过程后, 引人休斯 敦乡土植物, 打造拥有丰富动植物资源的潮间带湿地, 以提升场地的 生物多样性。对饱受夏季洪涝灾害影响的休斯敦市而言, 大面积不透 水硬质铺装是造成洪涝灾害的主要原因 ${ }^{[14]}$ 。中国的六盘水明湖湿地公 园、金华燕尾洲公园等海绵城市建设实践为场地对洪涝的适应提供了 借鉴 ${ }^{[15]}$ 。疏浚材料堆场通过湿地修复后, 可提供除河道以外的自然行洪 通道——湿地作为河道两岸的可淹没区域, 可减缓径流速度, 建立与
洪水相适应的韧性景观。

场地中的浅海区域水温适中、营养丰富, 并且区域二拥有生蚛养 殖历史, 非常适合运用生蚛礁进行生态修复。设计在区域二南端浅海 缓坡区以牡蚛壳填充圆柱形单元构建礁体, 圆柱形形态本身也呼应了 休斯敦港常见的石油油罐造型, 强调了港口工业文化的独特性。

此外, 在区域二以南的海域内, 仅有一处直径为 $160 \mathrm{~m}$ 的人工鸟 岛, 完全不能满足大量候鸟迁徙停留的需求。与此同时, 需要建设更 多的疏浚材料堆场来承载不断产生的疏浚泥沙。为此, 设计对区域二 最南端的一处疏浚材料堆场人工岛进行扩容, 并实施鸟类栖息地林地 植被演替, 使其发展成为独立的候鸟岛。在平面形态上, 设计团队大 胆借鉴迪拜棕榈岛、多伦多多处标志岛的成功经验, 以PHA标志为原 型, 将岛屿外轮廓改造成钴齿状, 以增加水岸线长度并丰富岸线类 型, 有利于鸟类直接进人水域, 尤其是为幼鸟提供庇护空间 ${ }^{[16]}$ 。同时, 从岛屿中心向外依次排布林地、草甸区、浅水区和深水区, 保证候鸟 栖息地的丰富性（图7）。

整体生态岸线的修复是海湾区域范围内减少石油工业污染的有力 措施。空间治理将场地闲置的土地与生态修复相结合, 可实现对空间 的有效整合; 修复后的水域生态环境则可以提高海滨生态系统的稳定 性, 同时实现疏浚废料的再利用。

\section{3 增强互动: 创造临港活力空间}

经过与休斯敦市政府和PHA的讨论, 设计团队认为, 如何拉近港 口与城市的关系、增强互动, 是为港城发展带来新动力的首要问题; 要激活工业港口空间、丰富港口职能, 就需要在场地中引人更多的第 三产业及公共活动, 增强市民及游客与场地的互动。其中一个难点是
5. 从水牛河向下游观景, 可以看到作为港口门户 的新建慢行跨河桥梁连 通南北两岸社区, 与具 有历史纪今意义的铁路 桥梁的背景相得益彰。

5. The new Port Gateway Bridge connects the communities on both sides of Buffalo Bayou, and the historical rail bridge layered in the background view is preserved as the city's heritage.

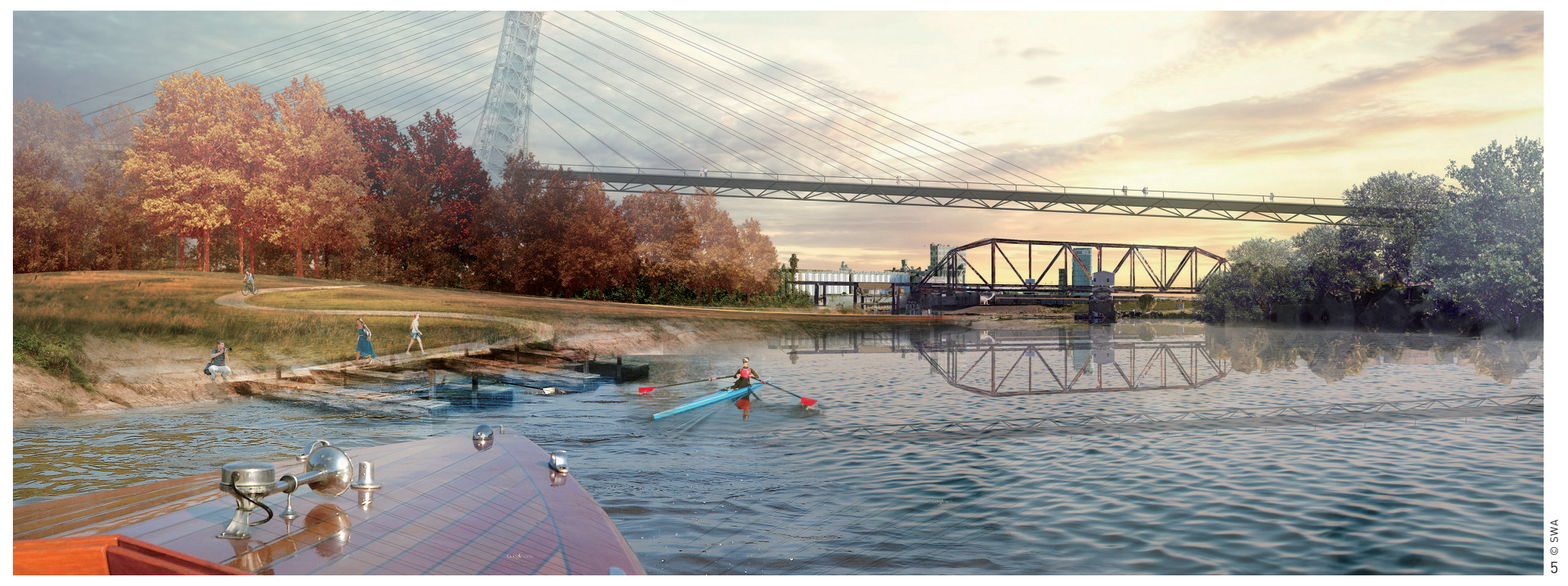


阿特金森岛上已经建成 的生态修复示范湿地, 通过利用净化后的疏浚 泥沙填充并开展植被演 替，现已初见成效。
6. An ecological

restoration pilot project

on Atkinson Island. The

dredged material is

refilled into the island

after purification,

and the vegetation

secession brings a nice

wetland back to the

gulf.

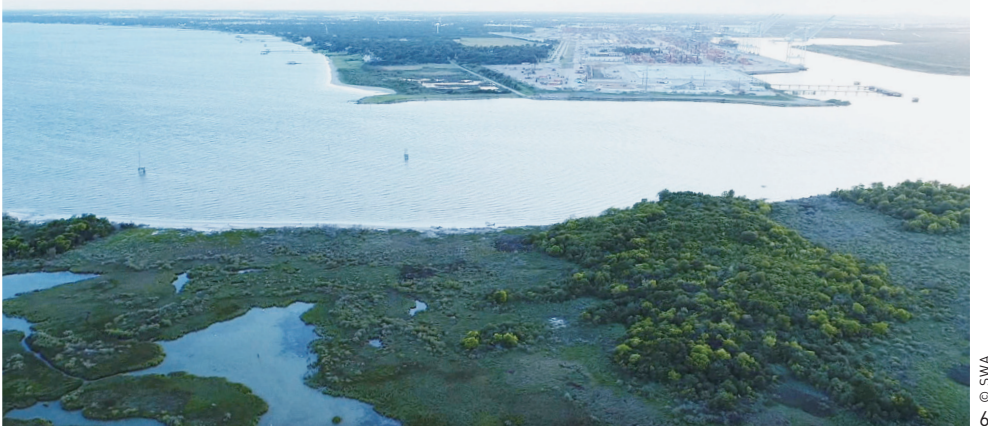

老旧的工业场地增添一抹亮色也是一种直接有效的途径（图14）。

设计以工业港口具有代表性的集装箱颜色为参考, 利用航道两 岸滨水平台的外立面形成连续的艺术廊道，同时选取场地上标志性的 工业厂房、粮仓等建筑物, 对其外立面进行艺术喷涂和标志图案设计 （图15）。设计还将这种艺术提升思路延伸到城市的主要交通干道及 其他城市基础设施上, 通过色彩喷涂和景观灯光装置等视觉引导方 式，大大增强港口与城市的空间融合氛围。

\section{4 公众参与及总体规划实施}

东俯瞰直通海湾的港口全貌，向西北欣赏休斯敦市中心的天际线。在 区域二北端设置标志性热气球观光点, 游客可以乘坐热气球欣赏人海 口壮阔的自然风光及工业作业过程（图10）。此外, 为了有效利用腾 退出的工业空间, 设计保留了拥有悠久历史的棉花仓库, 将之改造成 为南岸重要的艺术家中心, 为周围社区创建新的热点空间; 在腾退拆 除的建筑空地上规划建设具有港口工业特色的集装箱集市广场（图 11 ），将区域一即将腾退的集装箱码头打造为餐饮店、水上娱乐休闲 岛等城市目的地。

除了城市公共活力空间外，自然生态体验也非常重要。在现场踏 勘过程中, 设计团队在区域二的水域感受到了海湾作为港口门户的波 澜壮阔, 希望通过融趣味性和科普性为一体的生态旅游, 让更多访客 感受海湾内壮美的自然景观（图12）；定期组织市民参与到维护位于 区域二南端浅海缓坡区修复牡蚛壳礁的志愿者工作中（图13）; 利用 疏浚材料堆场闲置空间，以圆柱形结构来分隔不同的种植设计空间， 形成季节性景观花海; 生态修复中建立的候鸟岛将为游客提供珍贵的 观鸟科普资源; 在区域二构建整体生态观光步道, 沿途结合生境科普 展览和植被科普标识系统, 连接花海、告蚛礁、观鸟露台、露营营区 等自然生态体验空间。

\section{4 提升品质: 打造艺术景观廊道}

从城市界面打造整体艺术景观廊道、进行视觉引导也是本项目空 间品质提升的重要内容。考虑到休斯敦港是一个正在运行的大型港口, 能够改造再利用的开放空间有限, 设计团队认为, 通过艺术手法给原本

\section{1 公众参与及协同合作}

在美国，公众参与一直是景观设计中的一项重要工作，它能够促 进设计师与场地使用者的直接沟通。有别于中国普遍运用的以走访公 众和方案展示为主的场地前期调研模式, 美国的公众参与工作需要有 组织地选出非营利机构、企业及社区居民代表, 在项目之初让普通市 民有机会对场地设计表达自己的想法。而本项目的公众参与由于涉及 多个大型社区组团、企业和生态资源保护机构, 设计团队在传统的公 众参与模式上做出改进：通过ArcGIS和人口统计数据对场地周围的产业 类型、人口分布情况和相距港口空间的距离进行分析，确定各个分区 的受众范围, 并分别选举代表参与公众会议, 从而了解民众对港口的 认知程度; 并以设计工作坊的形式让居民自己在地图上绘制出可接受 的日常休闲空间距离、喜爱的活动地点及休闲娱乐形式（图16）。分 区式公众参与模式能够将公众对场地的反馈意见落实到港口内的各个 片区，相较笼统地收集意见更加有效。

在此过程中, 许多周边社区的居民设计了多样的港口参观形式, 并表达了登上游轮参观航道的意愿; 而自然保护组织也提出了鼓励游 客参与保护区建设工作的期许; 居民普遍对滨水滨海活动抱有极高热 情, 纷纷在港口人海口设计了徒步、露营、海钓等能够亲近自然的场 所; 另外值得关注的是, 很多居民希望把自己经常通行的机动车道路 改造为安全的步行或骑行空间, 以满足社区之间的联通和户外运动的 需求。这些公众参与反馈意见为设计团队带来了诸多启发。 
由于长年关注经济发展，政府将港口的发展优先于城市公共环 境的整体规划，使得城市空间未得到有效的综合利用，滨水工业区发 展存在根深蒂固的问题，也面临着复杂挑战。因此，在未来规划实施 阶段, 除了物质空间上的改造与修复，在机制上仍要持续融人公众参 与。港口管委会已委托 SWA 集团为主要咨询单位, 定期组织与政府、 企业、居民之间的沟通交流，并负责推进和调整长期规划方案。

\section{2 分期规划实施}

项目计划分三个阶段逐步推进。区域一的规划设计以近期规划为 主, 依据港口可转换为公共用地的先后顺序, 在保证港口正常安全运 转的前提下, 将整体场地腾退再开发; 区域二主要在确保生态环境安 全的基础上, 针对生态修复及生态旅游开发进行远期规划（图17）:

1 ) 阶段一 (2018-2025年)：完成区域一城市公共活动空间的改 造建设, 以及城市艺术景观廊道的空间品质提升; 依照 2045 规划, PHA 和USACE将完成疏浚材料堆场的扩容和结构新建工程, 为生态修复提 供保障。

2 ) 阶段二 (2026-2035年): 完成城市一港区慢行系统的建立; 大体完成生态修复设计中植被演替的初步过程, 形成较为多样的生境 和动植物群落; 推进牡蚛礁生境修复及人工鸟岛的自然环境演替。

3 ) 阶段三（2036-2045年）: 完成生态旅游配套设施建设, 建成 城市生态活力空间; 完善已经修复的生境和生态廊道, 进一步增加生 物多样性; 规划新的疏浚材料堆场, 为航道抵抗风暴潮汐提供保障。

规划实施之前将进行分阶段可行性研究, 以生态修复、增强生态 㓞性为首要任务, 合理分配资源。在上述三个阶段中, PHA作为总协调 方进行阶段性进展评估; USACE为环境质量总监控方, 确保各个阶段 生态修复和动植物群落发展的推进; 设计团队在每个阶段中协助收集 公众参与意见, 对已建成的公共空间进行使用后调研, 并结合反馈意 见相应调整下一阶段的设计内容。

\section{5 讨论与评述}

近年来，希望通过景观设计实现城市空间治理、激活滨水空间景 观设计及环境修复的研究与实践备受关注。有别于大部分已经废弃的 工业区改造, 休斯敦港景观规划设计项目以保证大型工业港口的正常 运营为前提开展景观规划设计, 针对城市发展定位及现状问题统筹规 划各类型城市空间, 实现了经济、社会、生态空间的相互融合, 推动 占据大量城市空间的工业景观向多功能系统转变。

休斯敦港景观规划从城市及生态两大框架人手统领景观设计策 略，一方面通过空间品质提升回应市民需求，另一方面将港口土地及 水域空间置人更大的生态系统尺度, 增强城市应对自然灾害的韧性, 进而提升海湾生态系统整体品质。

作为影响城市空间职能的重大规划决策, 设计之初的详尽现场调 研及受众群体调研讨论会至关重要。这需要基于经济社会学视角和景

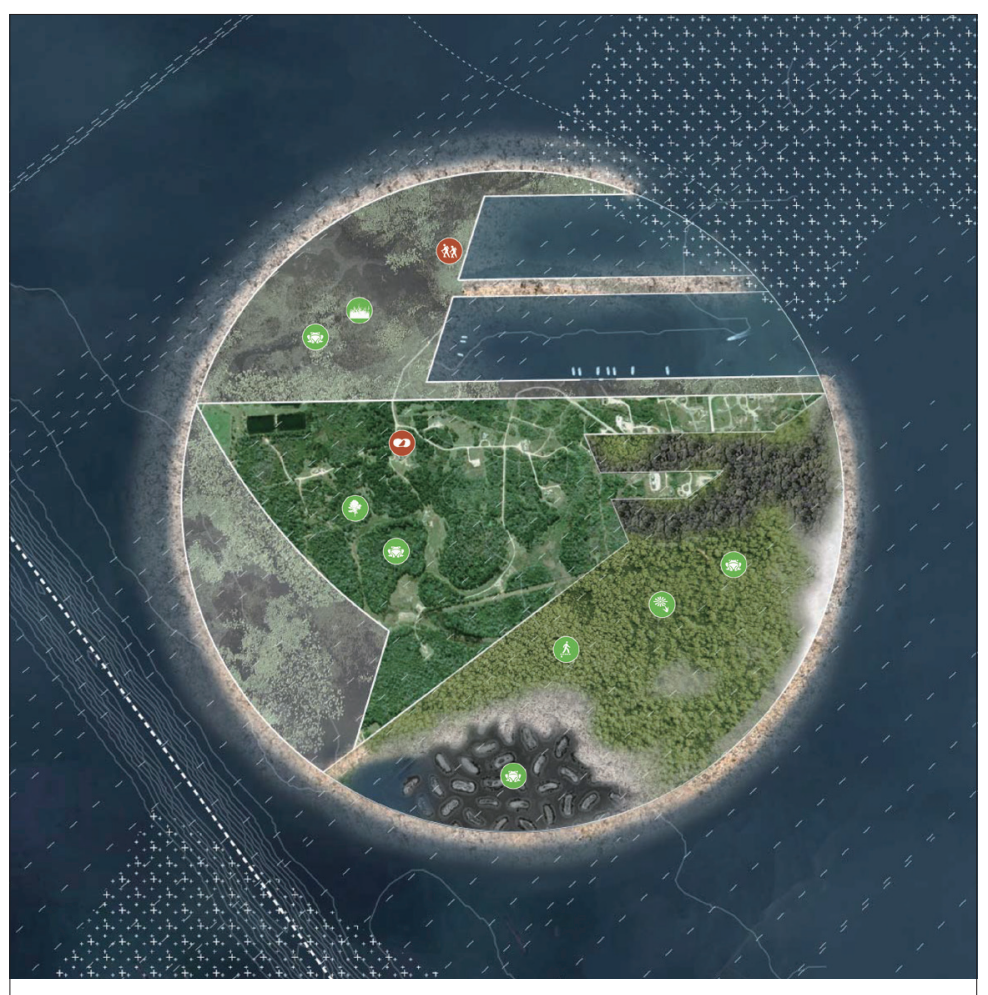

区域二基于现有的疏浚 材料堆场, 结合PHA标 志设计了人工鸟岛。

7. The design integrates the PHA logo with the existing Dredged Material Placemen Area in Area 2 and expands it into a migratory bird island.

\section{* 籍火 Firepit \\ (8) 艺术 Art}

被动休闲项目 Passive

(1) 眺望台 Overlooks

(1) 观鸟中心 Bird watching center

(2) 观测制高点 Observation high point
主动休闲项目 Active

( 5 5公里环型步道 $5-\mathrm{km}$ loop

‥ 多用途步道 Multi use trail

6. 自行车道 Bike trai

自然环境项目 Natural

林地修复 Forestation

옹 野花花田 Wildflower field

野生动物栖息地 Wildlife habitat

슬 自然教育 Nature education

草原修复 Prairie restoration
观设计专业视角, 积极开展社区意见收集、经济职能相关产业调研、 社会文化发展及生态保护情况梳理、上位规划及政府意见收集等全方 位的相关分析。此外, 针对规划类景观设计项目, 不仅需要景观设计 师从设计的角度对场地做出某一静态时间点的改造设计，更需要以动 态的前瞻性思考，综合制定近远期规划策略。LAF

\section{项目信息}

项目地址：美国得克萨斯州休斯敦市

项目面积: $45 \mathrm{~km}^{2}$

项目委托：休斯敦港务局

景观规划设计：SWA集团休斯敦分公司

首席设计师: Kinder Baumgardner

设计团队: Natalia Beard、Michael Robinson、Amna Ansari、王娜、蔡亚群、Alison Ecker、Abdallah Calal、Andre Rioux、邰子轩、朱洲飞

设计时间: 2017 年6 8月 


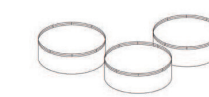

石油油蠸再利用 Refinery tank reuse

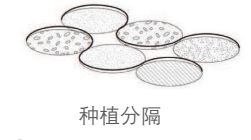

Control planting pattern
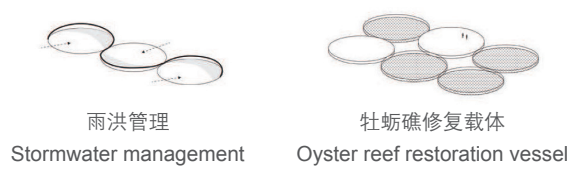

遮蔽构筑物 Shelter

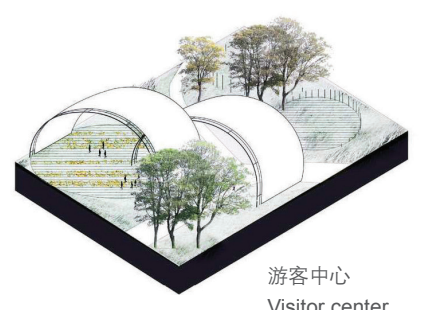

Visitor center

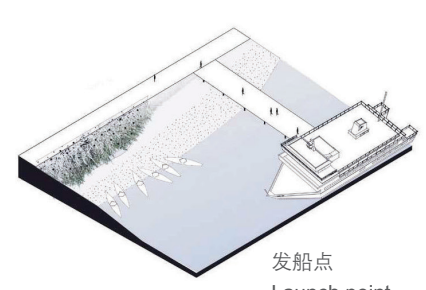

Launch point
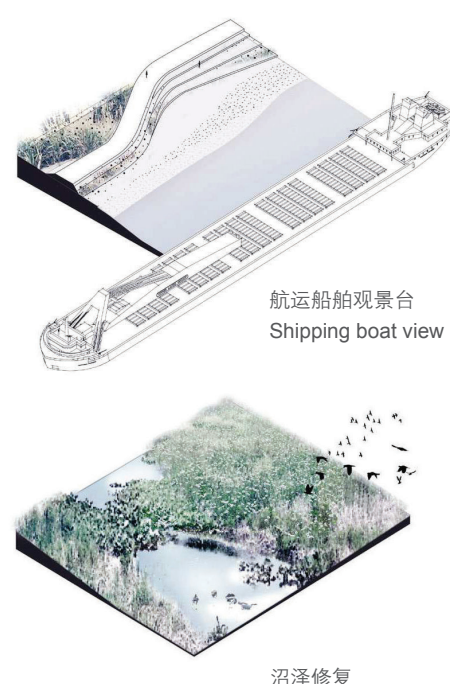

Marsh restoration
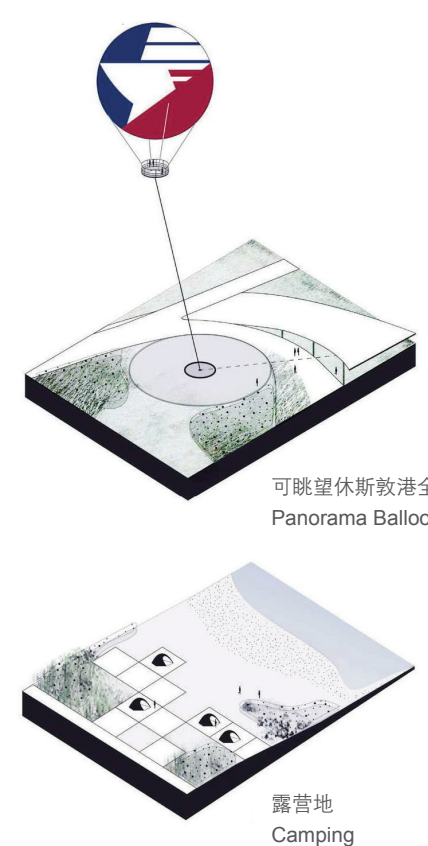

露营地
Camping

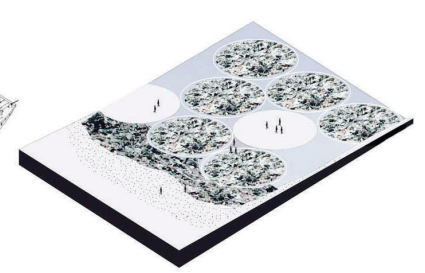

牡蚛礁和科普教育区域 Oyster reef and educatio
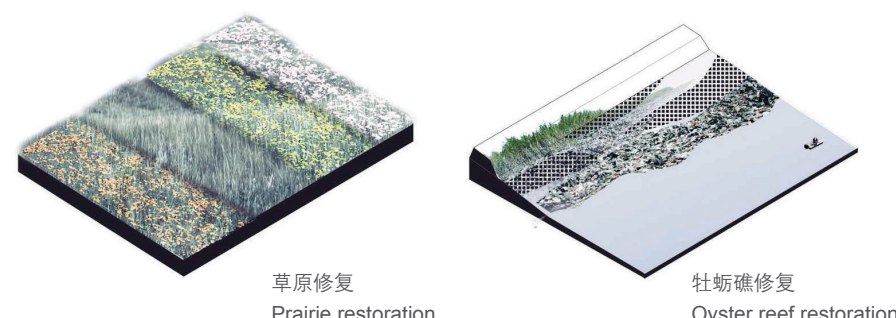
了场地上特有的石油工
业景观, 并按照人工维
护干预程度、活动密集 程度进行分类设计。

\section{Design prototypes of landscape elements borrow the formal language of industrial forms from the surrounding area, and set up programs that vary from "more maintained" to "less maintained," from human activity- concentric to nature- concentric.}

\section{Background Introduction}

The Port of Houston, Texas, United States integrates multiple location advantages such as transportation and ecological resources of the oil industry, with the ship channel's length of about $84 \mathrm{~km}$ in total. Over the past century, the Port of Houston has been a major driver of economic growth of Texas, bringing nearly 1.35 million jobs and economic outputs of USD 339 billion, which represents $20.6 \%$ of the Texas $\mathrm{GDP}^{[1]}$. However, in terms of spatial organization, there is a lack of interaction between the port with the city and citizens. At the same time, the continuous development of large ships increases the demand of waterway dredging, and the sediment accumulation generated by dredging projects also occupies the surrounding natural spaces. Galveston Bay, where the port is sitting, is under the long-term impact of sea level rise and port industrial development, resulting in the continuous deterioration of ecological environment and serious loss of biodiversity.

To better responding to future challenges, the Port of Houston Authority (PHA) has proposed "2045 the Port of Houston Master Plan” (the 2045 Plan hereafter), while collaborating with the United States Army Corps of Engineers (USACE) to ensure the ecological and environmental safety of waterways and surrounding waters. The Landscape Planning and Design for the Port of Houston project described in this article takes the 2045 Plan as an opportunity to improve the ecological, cultural, and social qualities of the port, in order to build the port into a compound waterfront industrial zone that meets the current and future needs of the city through landscape design.

\section{Project Investigation and Problem-Finding}

The site of this project consists of two areas. Area 1 covers the west end of the port, where there are a large number of abandoned factories left by industrial vacation-retreat; buildings such as the visitor center and PHA headquarters are also located here. Area 2 is located at the estuary of the port to the Galveston Bay, adjacent to the large dock of the Port of Houston, covering the gateway to the port. There are many constructed islands piled up by dredged sediment (Fig. 1).

At the beginning of the project, the design team exchanged views with PHA and conducted detailed site investigations by water and land. At the same time, through symposiums with management departments and mayors to understand environmental, economic, and cultural development of the surrounding cities. 


\subsection{Separation between the Port and the City}

By studying the industrial development of the Port of Houston and collecting the feedback of public participation, the design team found that the close connections between the port and the city are fading away. Historically, the port had been surrounded by a rich variety of productive transactions and recreational activities-the city was born from the port, and the port economy supported the development of the city. However, the benign interaction has been limited by the city's single secondary industrial development. In the past few decades, Houston witnessed an inland-toward expansion, entering a process of self-growth ${ }^{[2]}$ away from the port. Due to safety concerns, several kilometers of iron fences were built between the port and the city. Most of water area is isolated from the urban living area, with very limited spaces open to the public. As a result, it is difficult for citizens to access to the port area for leisure or recreation, while the port lacks opportunities to showcase its services to the city. As the largest industrial port in the United States, the Port of Houston is almost completely separated from the City of Houston.

Houston, as one of a very small number of American cities which have not developed any zoning plan, accommodates 6 early built large residential communities along the waterways that lack of supporting infrastructure planning, and only scattered community parks were built in recent years. In addition, the port forced a split of these communities geographically, making them isolated from each other, thus social interaction is only limited within individual community.

Moreover, the future urban positioning and development momentum of Houston still rely on whether the port can introduce derivative industries of manufacturing, including financial industry, tourism, and service industry related to the port.

\subsection{Industrial Ports Encroach Ecological Space}

Different from most other coastal ports, industry of the Port of Houston covers, in addition to linear waterways, more than 600 $\mathrm{km}^{2}$ of the entire gulf waters, including coastal prairie, forest meadow, wetland, oyster reef, marshland ${ }^{[3]}$, and other habitat types, providing homes for a large number of plants, fish, and other wildlife species. More importantly, Houston is located along the North American Central Flyway ${ }^{[4]}$, for which its urban forests and wetlands are a crucial stop point for migration birds. However, the development of the port encroaches a large amount of natural space, the Dredged Material Placement Areas ${ }^{(1)}$ at the estuary destroyed the habitats of migratory birds. Furthermore, the pollution of oil spilled in the gulf makes aquatic biodiversity drops dramatically ${ }^{[5]}$. The traditional mariculture and fishing industry disappear, the glorious plant and animal paradise is replaced by the scene of mechanical operation and shipping industry.

\subsection{Space Wasting of Dredged Material Placement Area}

Through field investigation, the design team found that a large number of Dredged Material Placement Areas were distributed in both design areas (Fig. 2), but mostly covered with wild vegetation. The treatment of dredging materials has been a hot topic in the development of waterway. Dozens of kilometers of waterway in the Port of Houston requires continuous dredging projects to maintain the draft depth requirement of ships. The large amount of engineering and the huge cost of manpower and material resources are rarely challenging other large industrial ports (with compact space arrangement) in the United States (such as Seattle, New York, and Los Angeles). There are 15 Dredged Material Placement Area along the coast of the Port of Houston ${ }^{[6]}$, and the annual cost of waterway dredging is as high as USD 70 million $^{[7]}$. As several existing Placement Areas have reached their maximum capacity, the 2045 Plan proposed to expand several of them and build new ones. ${ }^{[8]}$ How to reuse the idle placement spaces that has reached the maximum capacity challenges the port's future development.

\section{Design Strategies}

By studying other landscape planning projects for waterfront industrial areas, including the East Detroit Riverside Area Planning Framework ${ }^{[9]}$, Manhattan Waterfront Planning and
1) Dredged Material Placement Areas are sites accepting soils that have been dredged from the Houston Ship Channel. The site management process includes carefully dewatering and ditching a site to dry, after receiving dredged material.
9. 通过观景瞭望塔可以欣 赏到港口博物馆, 以及 掉头港码头的工业作业 全景。

View from the observation platform: visitors can get panorama views of port museum and the u-turn basin with industrial working scene.

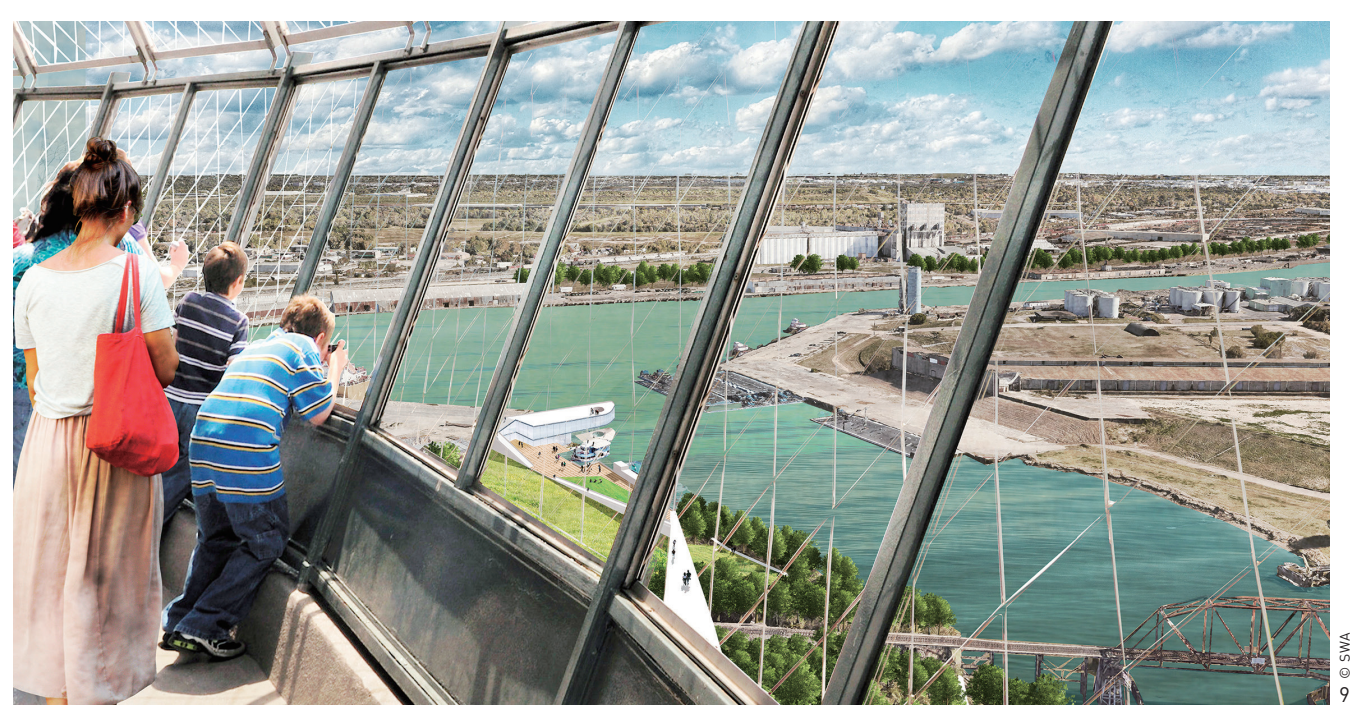


10. 区域二设计了热气球观 光点, 可以俯瞰海湾壮 阔的景色, 并近距离饱 览湿地景观及航道内 工业船只通航的繁比 景象。

10. View from hot-air balloon: visitors can get magnificent panorama of the gulf with the natural scenery of foreground wetland and the operation scene of industrial shipping.
Design $^{[10]}$ in New York, and Portland Waterfront Industrial Transformation ${ }^{[11]}$, the design team summarizes the principles of industrial waterfront management: under concepts of ecological restoration, the planning and design increase the city's ecological resilience by leveraging the services of urban waterfronts, improving space dynamic and enriching the diversity of urban space use.

To respond to the site issues, the project prioritizes urban activation and ecological landscape restoration, and formulates 4 design steps. First, reconnect the city and the port by enhancing spatial and social flows. Second, restore the basic ecological function of the site through environmental management. Third, create rich and varied public activity spaces, activate the port area, and improve social services. Finally, introduce art designs to integrate the port with the city and promote the cultural services of the waterfront industrial area.

\subsection{End the Isolation by Establishing City-Port Slow Traffic System}

Since the City of Houston does not have zoning plan, the absence of sidewalks in the city's transportation network leads to a high pedestrian fatality rate. The design team collected the public participation feedback on the need for safe outdoor walking and cycling routes, and created a slow traffic system connecting the port area and the urban communities. The design combines with the undergoing urban green trail network, develops cycling and walking lanes, and establishes a safe slow road network on the community scale. Thus, communities are connected, and the port area is attracting people and providing them with social and leisure opportunities (Fig. 3, 4).

The biggest challenge in the construction of slow traffic systems is to coordinate the pedestrian / bicyclist circulations with the port industrial transportation. The design team and PHA held a series of discussions and site surveys to ensure the design would not impact the existing vehicle traffic loop on the site while reducing the number of vehicle lanes and increasing spaces for walking and cycling. In addition, the port operation space is compacted with efficiency, only reserving the iron fence in part of the operation area that needs safety protection. The design also preserves the bridges of the waterway system as historical landscape heritages, and builds new paralleling bridges across the river to link up the surrounding community parks, ending the geographical isolation of communities on both banks (Fig. 5).

\subsection{Spatial Governance through Ecological Restoration}

The design team gradually restored the natural ecosystem invaded by industrial development and enhanced the ecological

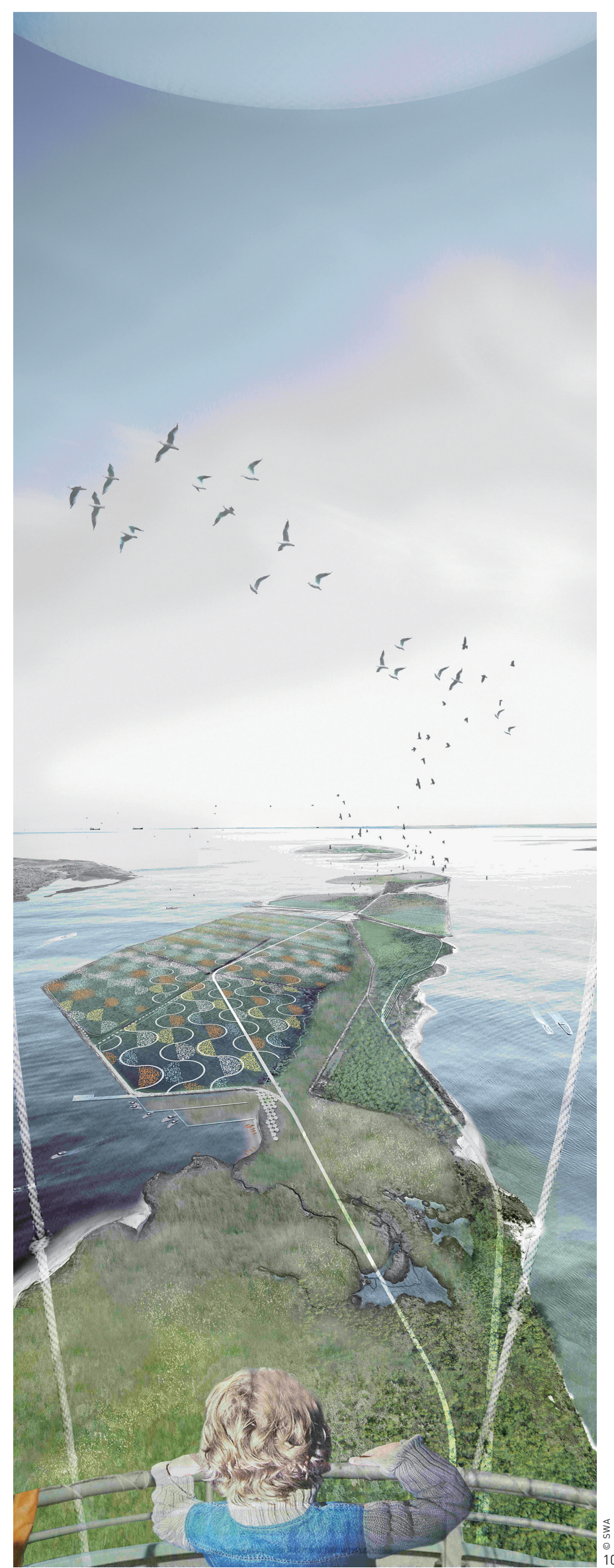




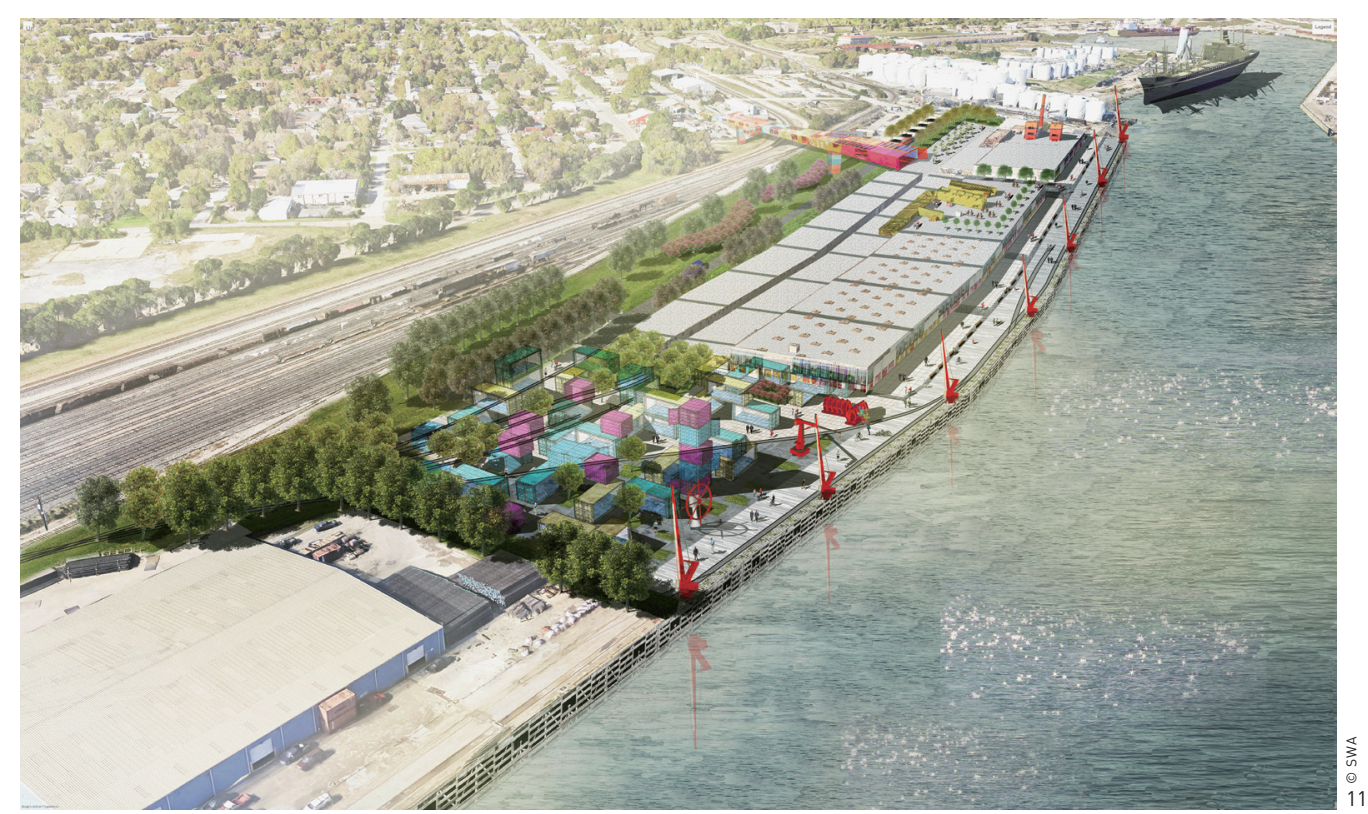

11. 区域一中集装箱集市和 工业改造的艺术中心为 市民打造丰富的城市文 化特色活动空间

12. 区域二利用已经达到最 大容量的堆场开发生态 旅游空间, 花海景观将 成为吸引市民及游客的 特色活动空间。

13. 牡蚛壳礁生境修复及科 普教育: 招募志愿者积 极参与到生境保护的工 作中, 并定期举办科普

讲堂。
11. Container village plaza and art market in Area 1 provide diverse urban activity spaces for citizens.

12. Flowering landscapes in Area 2 provide diverse eco-tourism activities for citizens and tourists, creating public spaces of Dredged Material Placement Areas which reach the maximum capacity.

13. Oyster reef restoration and education site: Volunteers will help maintain the habitat with education sessions for visitors. resilience of the coastal industrial zone through Dredged Material Placement Area purification and redevelopment, shoreline restoration, and reconstruction of migratory birds habitats.

As a working industrial port, it is difficult for the design team to directly introduce a large area of public green space into the site, while the waterway must also meet the navigation requirements. A lot of vacant Dredged Material Placement Areas on the site become a focal point for redevelopment. For many years, PHA has launched a pilot project which restores several Placement Areas within Area 2 into wetlands with dredged sediment ${ }^{[12]}$ (Fig. 6). This 50-year-spanning project ${ }^{[13]}$ would introduce native plants and increase biodiversity by creating intertidal wetlands as animal and plant habitats, after the Placement Area reaches its maximum capacity and finishes the precipitation and dehydration process. Besides, for the City of Houston, which suffers from severe summer floods, the large area of impermeable hardscape paving is the main cause of floods ${ }^{[14]}$. The practice of sponge city construction in China, such as Liupanshui Minghu Wetland Park and Jinhua Yanweizhou Park, provides references for the site's adaptive design to floods ${ }^{[15]}$. After the Dredged Material Placement Areas become restored wetlands, they can act as natural flood drainage (in addition to the ship channel) and inundable riparian areas which can also slow down runoff, establishing resilient landscapes.

The shallow sea area of the site has moderate water temperature and rich nutrients; moreover, Area 2 enjoys an oyster cultivation history, making it suitable to use oyster reefs in the ecological restoration. The project designs oyster reefs at the gentle slope in the southern edge of Area 2. The reefs are constructed with cylindrical units filled with oyster shells-the cylindrical form echoes the oil tank shape at the Port of Houston and emphasizes the uniqueness of the port's industrial legacy.

In addition, there is only one artificial bird island (with a diameter of $160 \mathrm{~m}$ ) within the sea area to the south of Area 2, which cannot meet the needs of large numbers of migratory birds. Meanwhile, more Dredged Material Placement Areas are planned to build. To this end, the design expands the Dredged Material Placement Area in the southernmost part of Area 2, and restores it into a dedicated island for migratory birds by facilitating the vegetation succession of forests. By studying precedents such as Palm Island in Dubai and Landmark Islands in Toronto, the design team uses the PHA logo as the prototype for the layout design. The island is designed with serrated edge, in order to increase coastal length that would help birds directly access to the waters, particularly offering sanctuaries for young birds ${ }^{[16]}$. Forests, meadows, shallow water areas, and deep water areas are arranged outward from the center of the island in order to enrich the diversity of migratory bird habitats (Fig. 7).

The restoration of the entire ecological shoreline is a powerful measure to reduce the oil pollution in the gulf region. Spatial governance of the idle lands employs ecological restoration to realize the effective integration of space. The restored aquatic ecological environment would improve the stability of coastal ecosystem and the reuse of dredged wastes. 
3.3 Enhance Interaction by Increasing the Vitality of the Port

After discussing with the city government and PHA, the design team believed that how to reshape the relationship between the port and the city and enhance their interaction is the primary issue to be addressed before bringing new impetus to the port-city development. To activate the industrial port and promote its services, it is necessary to introduce more tertiary industries and public activities into the site, and enhance the interaction between the port and people-both citizens and tourists. One of the difficulties is how to reasonably create public activity places in the industrial port area. The 2045 Plan inspires the design team: the increasing size of ships requires a greater draft depth, which needs continuous expansion of channels. Moreover, the height restrictions on urban viaducts prevent
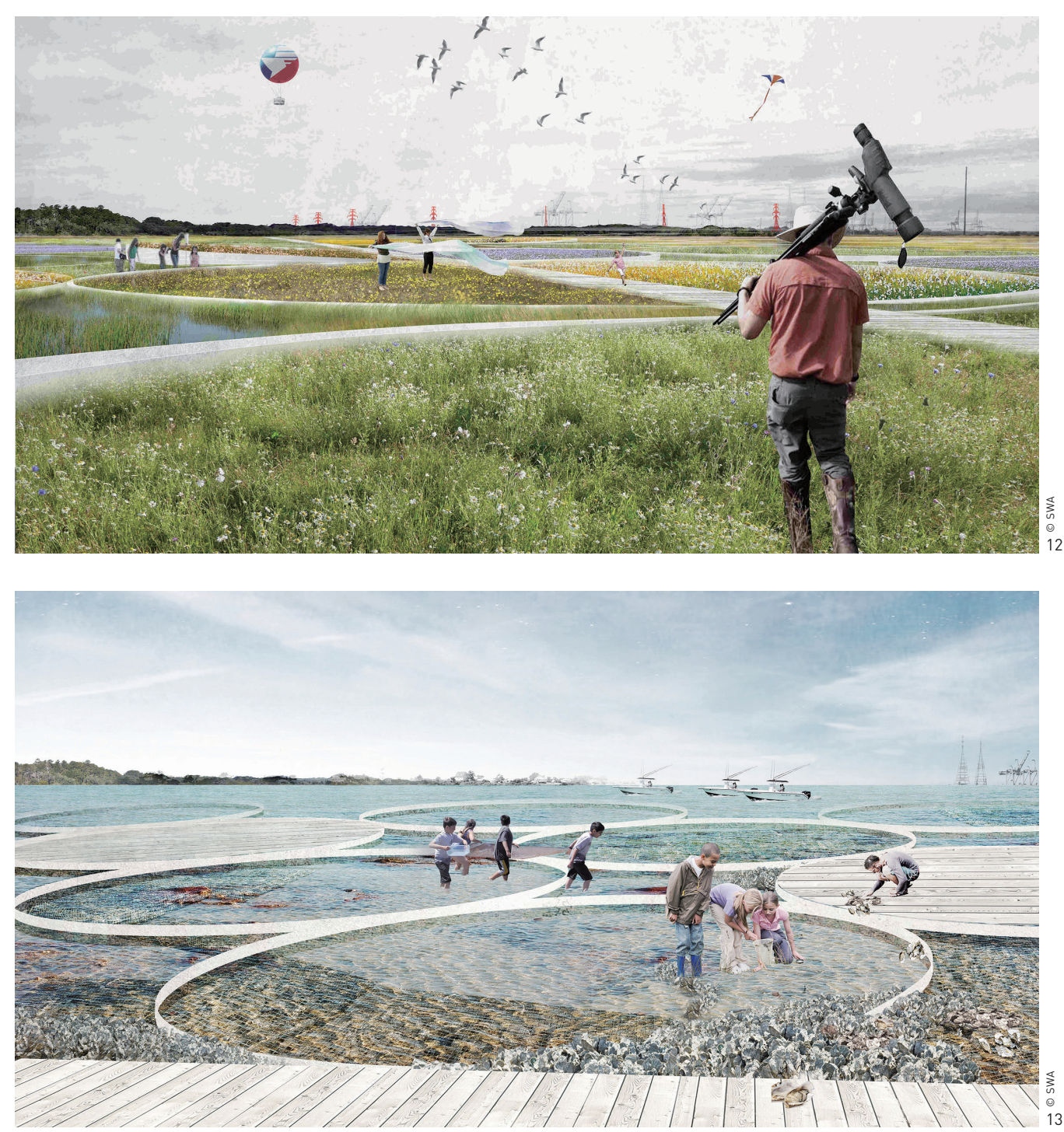

larger ships from entering the current u-turn port, making it imperative for the port to move downstream. By vacating the industrial lands of the port by stages and transforming them into urban public spaces as industrial heritages, more waterfront destinations will be created to the surrounding communities, and the mutual integration of the port and the city will be enhanced (Fig. 8). Such a phased design also echoes the strategic repositioning of the city's industrial land use.

The design builds a landmark observation tower in Area 1 (Fig. 9), from which visitors can enjoy the panorama view of the port to the east, and the downtown Houston skyline to the northwest. A landmark hot-air balloon is set up at the north end of Area 2. Visitors can enjoy the magnificent natural scenery and industrial operation scenes at the estuary (Fig. 10). In addition, in order to effectively utilize the vacated industrial space, the design retains the historical cotton warehouse and transforms it into an artist center on the south bank, creating a new hub for the surrounding communities. A container market square celebrating the port's industrial identity will be built on the vacant lot (Fig. 11), and the container yard in Area 1 that to be vacated will be built into new urban destinations such as restaurants and water entertainment islands.

In addition to urban public spaces, natural ecological experience is also very important. In the process of site investigation, Area 2, as the gateway of the port, gives magnificent views to the design team members. The design dedicates to bring magnificent natural landscapes to tourists combining with eco-tourism that integrates playful science education programs (Fig. 12). Restoration of oyster shell reefs in shallow and gentle slope in the southern edge of Area 2 introduces the public with regular volunteer work to maintain the habitat (Fig. 13). The idle space of Dredged Material Placement Areas is designed to form seasonal flowering landscapes with cylindrical units as planting bed separation. The established migratory bird island will provide tourists with precious scientific resources for bird watching. Also, an ecological sightseeing trail network is constructed in Area 2, which combines public education exhibitions of habitats and vegetation interpretation system. Overall, the trail network links up the flowering landscapes, oyster shell reefs, bird watching platform, camping area, and other ecological experiencing spaces.

\subsection{Improve Spatial Quality via Introducing an Artistic Landscape Corridor}

It is also an important part of this project to build an artistic landscape corridor that combines with urban interface design and helps with visual guidance. Given that the site is a 


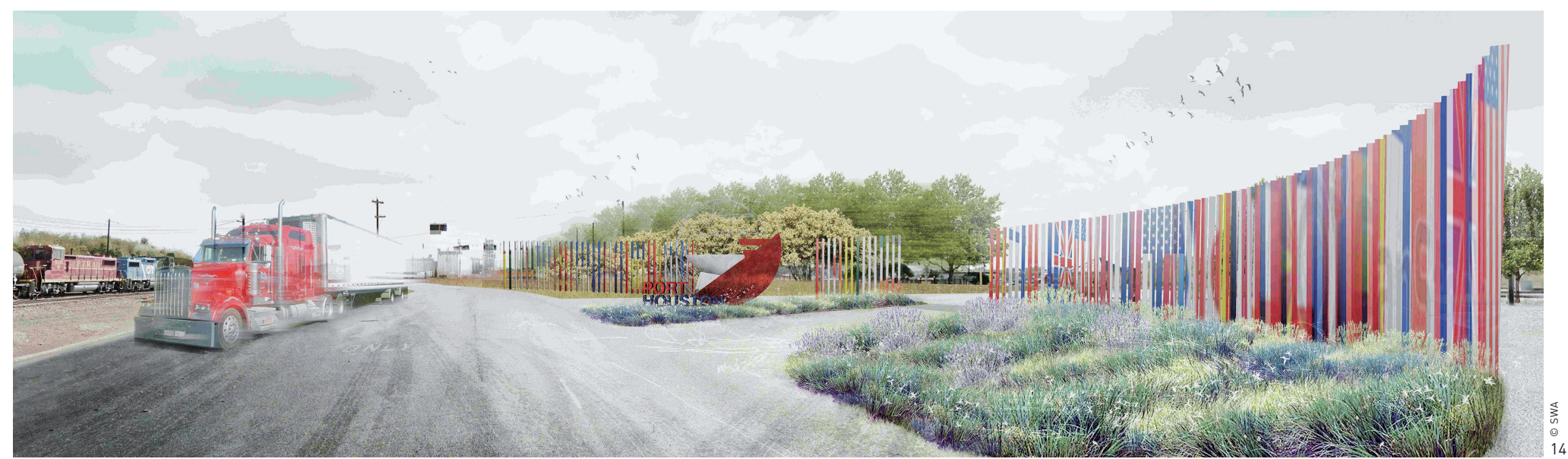

large working port with limited open spaces to be repurposed, color painting to the existing industrial structures and elements through artistic approaches is considered an easy and effective method (Fig. 14).

The typical color palette of containers in the port is used for the facade design of waterfront platforms on both sides to form a continuous artistic corridor; iconic industrial plants, granaries, and other buildings on the site are selected for color painting and logo design (Fig. 15). The design also extends the artistic approaches to the visual design of main traffic arteries and other urban infrastructure of the city with color painting and lighting installations, greatly enhancing the atmosphere of spatial integration between the port and the city.

\section{Public Participation and the Implementation of Master} Plan

\subsection{Public Participation and Coordination}

In the United States, public participation is always an important part of landscape design, which facilitates the direct
14. 休斯敦港门户景观结合 了港口工业集装箱标志 性色彩, 形成门户景墙 及标志雕塑, 成为主干 道上的特色景观节点。

15. 作为休斯敦港重要的对 外展示界面, 运用艺 术提升的手法将航道两 岸的工业立面进行艺术 喷涂景观提升，以工业 集装箱特色颜色为主色 调, 进一步实现空间品 质提升。

14. The Port Houston Gateway landscape design integrates typical container color palette with entry wall and logo sculpture.

15. As an important visible dimension of Port Houston, facades are its best advertising boards. Inspired by graphic qualities of shipping containers, both sides of the ship channel are improved by art installations.
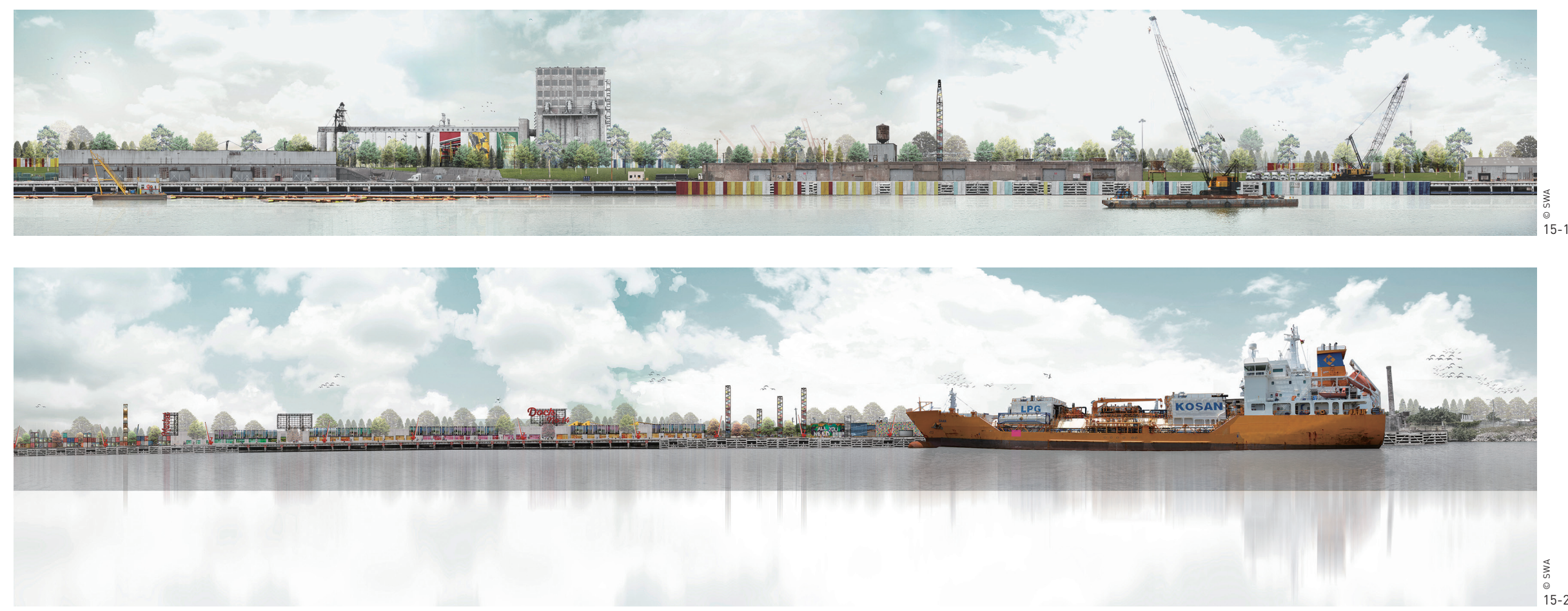

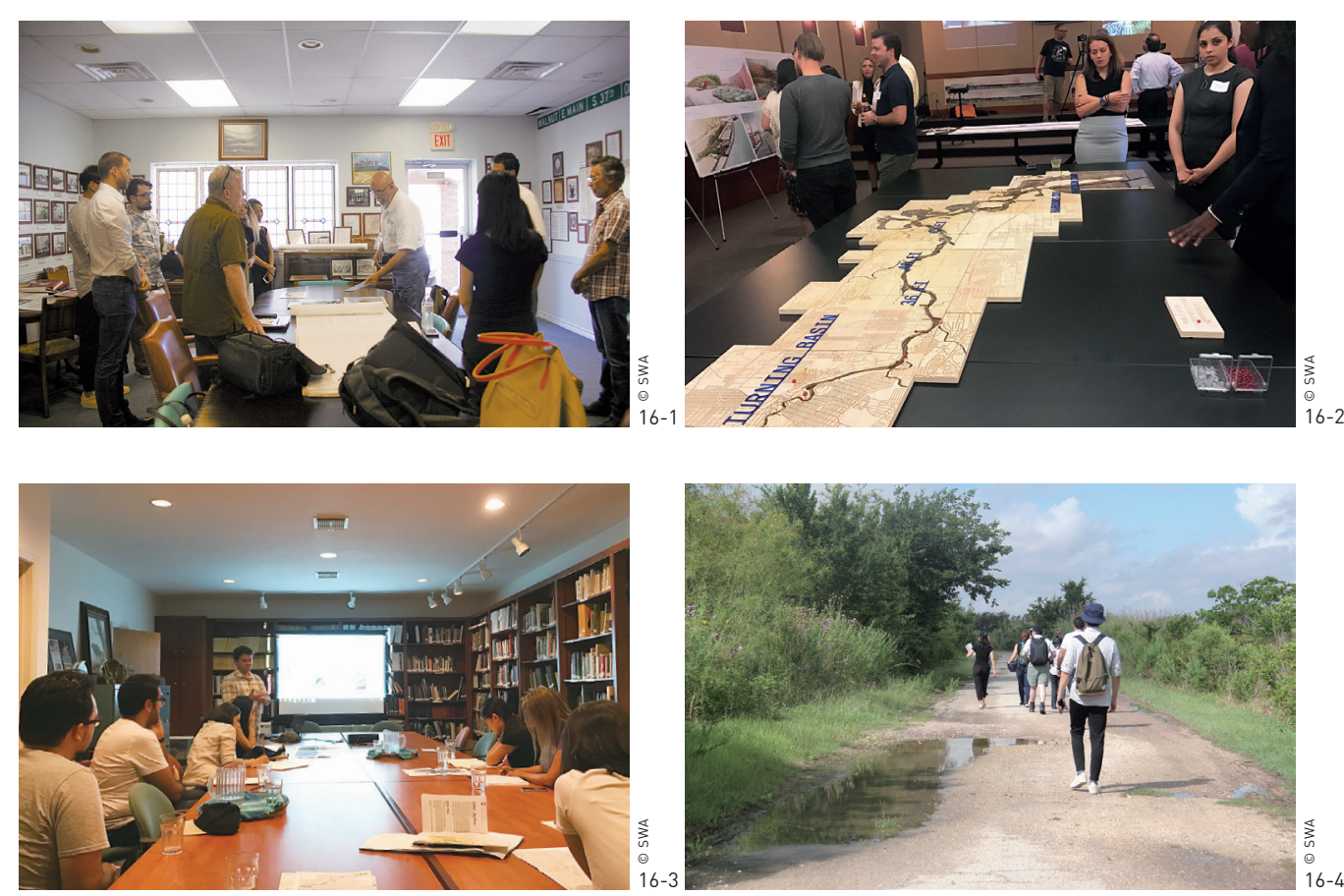

16. 公众参与及意见收集会 照片: 与临港各市市长 照片: 与海港各市市长 座谈 (图16-1); 公众 2 ）；与鸟类协会座谈 (图16-3); 自然保护 区调研 (图16-4)。

16. Community engagement and stakeholders meeting: With mayors of meeting: With mayors o coastal cities (Fig. 16-1); with communities on the final design presentation (Fig. 16-2); with Houston Audubon Society on bird habitat restoration (Fig. 16-3); with experts on the field survey of reserves (Fig. 16-4). communication between designers and site users. Different from the preliminary site survey mode widely adopted in China which is mainly in forms of user visits and design concept display, the public participation work in the United States needs to elect representatives of non-profit organizations, enterprises, and community residents in an organized way, so that citizens have the opportunity to express their ideas on the site design at the beginning of the project. Due to the large scale of this project, the public participation needs to cover a number of large communities, enterprises, and ecological resource protection agencies. The design team makes improvement on the pattern of public participation: based on GIS and demographic data, public participation zones were defined by industry types, population distribution, and the distance to the port area; elected representatives were invited to separate public meetings, to better collect citizens' ideas and understand their cognition of the port; in the form of design workshops, residents are allowed to map out the acceptable walking distance to their daily leisure spaces, favorite activity venues, and forms of leisure and recreational activities (Fig. 16). Comparing with the generic collection of public opinions, such a zonal public participation model can more effectively inform the design of specific areas within the port.
During the public participation process, many residents from the surrounding communities designed various forms of port visits and expressed their willingness to board cruise ships to visit the waterways. Conservation organizations have also raised the prospect of encouraging tourists to participate into the creation of reserves. Residents generally have a high enthusiasm for accessing the natural environment of the port, and have designed the places for hiking, camping, fishing, and other waterfront activities at the estuary of the port. Also, the desire to transform their frequently used motorized roads into safe walking or cycling spaces to meet the needs of community connectivity and outdoor sports has been emphasized. The feedback from public participation provided the design team with lots of inspirations and sources.

Due to the long-term attention to economic growth, the government gave priority to the development of the port over the overall planning of the urban public environment, which results in the ineffective utilization of urban space on the whole. There are deep-rooted problems and complex challenges in the revitalization of waterfront industrial areas. Therefore, in the future planning and implementation stage, in addition to the spatial transformation and restoration, public participation should continue to be integrated in the design process. PHA has entrusted SWA Group as the leading consulting team to organize regular meetings with the government, enterprises, and residents, and to be responsible for promoting and adjusting long-term planning schemes.

\subsection{Implementation of Phased Planning}

The project is planned in three phases. The planning and design of Area 1 is mainly for the coming several years. According to the converting schedule of port land into public areas, the whole site will be vacated and withdrawn for redevelopment, while ensuring the smooth and safe operation of the port. On the basis of ensuring the security of regional ecological environment, Area 2 carries out long-term planning for ecological restoration and eco-tourism development (Fig. 17):

1) Phase 1 (2018-2025): Complete the renovation and construction of the public activity spaces in Area 1, and improve the spatial quality of the artistic landscape corridor; Under the 2045 Plan, PHA and USACE will complete the expansion and structural construction of Dredged Material Placement Areas to support ecological restoration.

2) Phase 2 (2026-2035): Complete the establishment of city-port slow traffic system; Complete the initial process of vegetation succession of the ecological restoration, and enrich 


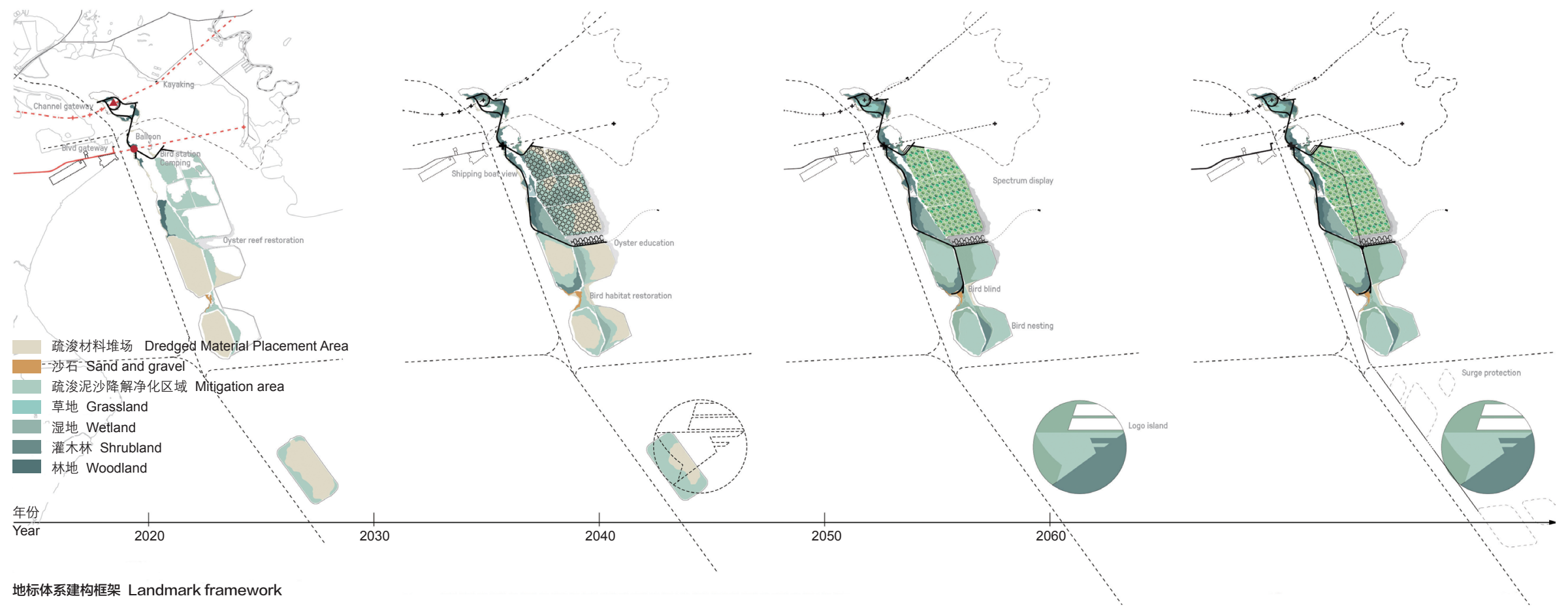

A电力线连接（航道门户: 电力塔)

Power line connection (channel gateway: power tower)

林荫道走廊连接（林荫道门户：从林荫道照明装置设计到洮望热气球，再到灯塔）

Boulevard corridor connection (boulevard gateway: from boulevard lighting to Panorama Balloon, to light tower)

疏浚材料堆场 Dredged Material Placement Area

\begin{tabular}{|c|c|c|c|c|}
\hline $\begin{array}{l}\text { 正在使用中的堆场 } \\
\text { Placement Area in use }\end{array}$ & $\begin{array}{c}\text { 堤防高度上升, 增加容量 } \\
\text { Levee level up, increasing capacity }\end{array}$ & $\begin{array}{l}\text { 已达到最大容量 } \\
\text { Reach capacity }\end{array}$ & & \\
\hline & & & $\begin{array}{c}\text { 新建疏浚材料堆场 } \\
\text { New Dredged Material Placeement Area generation }\end{array}$ & $\begin{array}{c}\text { 为抵御风暴潮汐而扩建疏浚材料人工岛 } \\
\text { Dredge isle }\end{array}$ \\
\hline
\end{tabular}

各规划阶段 Planning phasing

\section{A 现有的灌木林}

Existing shrubland

保留现有的草地、湿地和灌木林

Remain existing successions of grassland, wetland, and shrubland

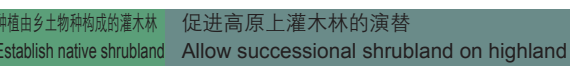

B 花海色彩谱带

Spectrum display

频谱展示按季节设计了不同色彩的种植方案, 以回 收石油油罐作为种植结构, 并融合管理雨水措施 Spectrum display establishes different colorful planting patterns seasonally, and recycles storage tanks as planting structures for establishing planting patterns and stormwater management

\section{C 疏浚泥沙降解净化区域} Mitigation area

在疏浚材料堆场达到最大容量并完成脱水过程后， 进行表层土壤管理, 以修复和提高土壤肥力, 使土 壤能够保证乡土草地植物群落的建立及后续的自然

After Dredged Material Placement Areas reach their capacity and complete the dewatering process, topsoil management proceeds to both remediate and improve soil fertility, so as to support the establishment of native grasslands and later successional stages
表层土壤 沿沟渠形态种植乡土草地植物群落 Establish native grassland along ditch pattern

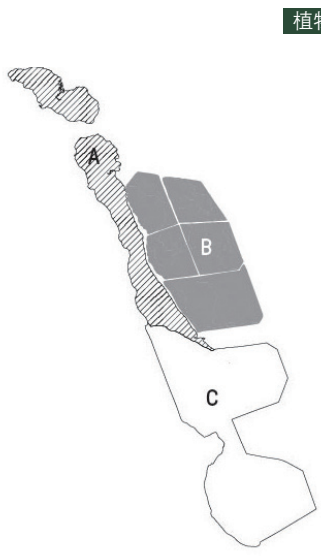

\begin{tabular}{c|c|c|c|} 
表层土壤 & 保留现有的草地、湿地和灌木林 \\
Topsoil & Remain existing successions of grassland, wetland, and shrubland
\end{tabular}

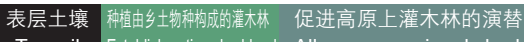

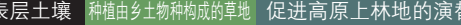

Ilsh native arassland Allow successional woodland on highland 
17. Area 2 Phasing Strategies: focusing on ecological restoration and bird island building. the diversity of habitats and animal-plant communities; Promote the restoration of oyster reef habitat and the natural succession of the constructed bird island.

3) Phase 3 (2036-2045): Complete the construction of supporting facilities for eco-tourism, and build vibrant urban ecological spaces; Improve restored habitats and ecological corridors to further increase biodiversity; New Dredged Material Placement Areas are planned to protect the channel against storm surges.

Before the implementation of the planning schemes, a phased feasibility study will be carried out, which would highlight ecological restoration and enhancement of ecological resilience, and coordinate the allocation of resources. In the above three phases, PHA is the general coordinator of the progress assessment; USACE is the supervisor of environmental quality to ensure the progress of ecological restoration and the establishment of plant and animal communities at all stages. The design team is in charge of collecting public participation opinions in each phase, conducts post-occupation investigation on built public places, and adjusts the design schemes of the next phase according to the feedback.

\section{Discussion and Reflection}

In recent years, the research and practice of urban space governance, waterfront space activation, and environmental restoration through landscape design have attracted broad attention by landscape professionals. Different from most of abandoned industrial areas, Landscape Planning and Design for the Port of Houston project requires to ensure the smooth and safe operation of large industrial port at first. Upon the city's development repositioning, the master planning of urban spaces responds to the current issues by mutually integrating economic, social, and ecological space, promoting the transformation of the city's large area of industrial landscapes toward a multifunctional system.

The project consists of two strategic frameworks: the urban and the ecological. On the one hand, the spatial quality improvement responds to public demands; On the other hand, the port is being designed as a component of larger-scale ecosystems, enhancing the resilience of the city against natural disasters, and improving the overall quality of gulf ecosystem.

As a major planning decision that would profoundly influence urban space's future development, careful field investigation and user group discussion at the beginning of design is vital. It is necessary to carry out comprehensive analysis such as community opinion collection, industry research on economic functions, sorting out the exiting social and cultural development and the ecological protection, implementation of upper planning and government policiesall of them should be conducted from perspectives of both economic sociology and landscape design. In addition, for landscape planning and design projects, designers not only need to come up with solutions from a static time point of the site, but also need to formulate comprehensive short- and long-term planning strategies with proactive, forward-looking thinking. LAF

\section{PROJECT INFORMATION}

LOCATION: Houston, Texas, USA

AREA (SIZE): $45 \mathrm{~km}^{2}$

CLIENT: Port of Houston Authority

ANDSCAPE PLANNING AND DESIGN: SWA Group, Housto

CHIEF DESIGNER: Kinder Baumgardner

PROJECT TEAM: Natalia Beard, Michael Robinson, Amna Ansari, Wang Na, Cai Yaqun, Alison Ecker,

Abdallah Calal, Andre Rioux, Tai Zixuan, Zhu Zhoufei

DESIGN PERIOD: June August, 2017

\section{REFERENCES}

[1] Martin Associates. (2019, April 5). The local and regional economic impacts of the port of Houston, 2018. Port Houston. Retrieved from https://porthouston.com/wp-content/uploads/ Port-of-Houston-EIS-State-Impacts-4-5-2019-1.pdf

[2] Chen, W., \& Wang, Y. (2006). On Interaction of Harbor and City Development. Chinese Consulting Engineers, (5), 22-23. doi:10.3969/j.issn. 1009-5829.2006.05.012

[3] Lester, J., \& Gonzalez, L. (2011). State of the bay: A characterization of the Galveston Bay ecosystem. Austin, TX: Texas Commission on Environmental Quality.

[4] Fall Migration on the Upper Texas Coast. (n.d.). Houston Audubon. Retrieved from https:// houstonaudubon.org/birding/resources/fall.html\#: :text=Houston's\%20position\%20on\%20 the\%20Central,Central\%20America\%20for\%20the\%20winter

[5] Harman, G. 12019. April 191. Assessing the Damage from the Galveston Bay Oil Spill. Retrieved from https://www.texasobserver.org/assessing-the-damage-from-the-galveston-bay-oil-spill/

[6] Channel development. (n.d.). Port Houston. Retrieved from https://porthouston.com/channeldevelopment/

[7] Leinfelder, A. (2020, February 13). Port Houston receives $\$ 70 \mathrm{M}$ for maintenance dredging. Retrieved from https://www.chron.com/business/bizfeed/article/Port-Houston-receives-70Mfor-maintenance-15053473.php

[8] Watkins, K. (2020, August 11). Proposal Would Help Protect Houston Area From Hurricanes, Create 10,000-Acre Public Park. Retrieved from https://www.houstonpublicmedia.org/articles/ news/energy-environment/2020/08/11/379574/this-proposal-would-help-protect-the-houstonarea-from-hurricanes-and-create-a-10000-acre-public-park/

[9] Skidmore, Owings \& Merrill. In.d.). Detroit East Riverfront Framework Plan. SOM. Retrieved from https://www.som.com/projects/detroit_east_riverfront_framework_plan

[10] Department of City Planning, City of New York. (March, 2011). Vision 2020: New York City Comprehensive Waterfront Plan. Retrieved from https://www1.nyc.gov/assets/planning/ download/pdf/plans-studies/vision-2020-cwp/vision2020/vision2020_nyc_cwp.pd

[11] Sasaki. (n.d.). Zidell Yards: Expanding Portland's Public Waterfront. Retrieved from https://www sasaki.com/voices/zidell-yards-expanding-portlands-public-waterfront/

[12] Texas Parks and Wildlife. (n.d.). Atkinson Island WMA. Retrieved from https://tpwd.texas.gov/ huntwild/hunt/wma/find_a_wma/list/?id=57

[13] Wagner, R. J. (2000). Houston-Galveston Navigation Channel: Blueprint for the Beneficial Uses of Dredge Material. Coastal Management, 28(4), 337-352. doi:10.1080/08920750050133593

14] Rice, J. (2020, February 13). Houston's New Resiliency Plan a Good 'First Step,' Expert Says. Houston Public Media Retrieved from https.//www houstonpublicmedia org/articles/shows/ houston-matters/2020/02/13/360473/houston-sets-once-in-a-generation-goals-in-disasterhouston-matters/202

[15] Yu, K. 12015). Three Key Strategies to Achieve a Sponge City: Retention, Slow Down and Adaptation. South Architecture, (3), 4-7. doi:10.3969/j.issn.1000-0232.2015.03.004

[16] The Royal Society for the Protection of Birds. (n.d.). Artificial Islands. Retrieved from https:// www.rspb.org.uk/our-work/conservation/conservation-and-sustainability/advice/conservationland-management-advice/artificial-islands/ 